\title{
The Possible Ameliorative effect of Zafirlukast on Renal Toxicity Induced by Methotrexate in Experimental Animals
}

\author{
Mohammed Fathy Abbas, Shereen Abd-elhakim El-sherbeney ${ }^{1}$ and Rasha F. Ahmed ${ }^{2}$ \\ ${ }^{1}$ Department of Forensic Medicine and Clinical Toxicology, Faculty of medicine, Minia University, Egypt. \\ ${ }^{2}$ Department of Biochemistry, Faculty of medicine, Minia University, Egypt.
}

\begin{abstract}
Methotrexate is a chemotherapeutic agent. Nephrotoxicity is an important side effect of treatment with methotrexate. Zafirlukast is a cystenyl leukotriene antagonist that acts as an anti-inflammatory and antioxidant agent. The aim of this study was to analyze the nephrotoxicity induced by methotrexate in rats and to evaluate the possible ameliorative effect of zafirlukast. Ethanol $(1 \mathrm{ml} / \mathrm{kg}$, orally once daily) and zafirlukast (40mg/kg, orally once daily) were given for 10 days. Methotrexate (20mg/kg I.P, single injection) and, zafirlukast (40mg/kg, orally once daily) was given 5 days before methtrexate and then 5 days after the chemotherapeutic agent. Rats will be sacrificed after the 10th day from methotrexate intake. Rats given methotrexate alone had significantly higher MDA (malondialdehyde), lower reduced glutathione, catalase, superoxide dismutase in kidney tissue and higher blood urea nitrogen and serum creatinine levels than the control groups. Co-treatment of zafirlukast with methotrexate had an ameliorative effect on the previous parameters. Light \& electronic microscopic pictures revealed that methotrexate caused marked degenerative changes in the kidney of rats. Restoration of the normal architecture of kidney tissues were observed in rats received methotrexate with zafirlukast. Thus, methotrexate can induce oxidative damage in rat kidney \& zafirlukast has an ameliorative effect against this damage.
\end{abstract}

Keywords methotrexate, nephrotoxicity, zafirlukast, oxidative damage

\section{Introduction}

Chemotherapy involves the use of chemical agents to stop the growth of cancer cells. Methotrexate (MTX) is a folic acid antagonist that's widely used in the treatment of malignancies as well as in the treatment of many inflammatory and autoimmune disorders (Weinblatt, 2013).

Methotrexate began to replace the more toxic antifolate aminopterin starting in 1950s (Miller, 2008). Methotrexate was originally developed and continues to be used for chemotherapy, either alone or in combination with other agents. It is effective for the treatment of a number of cancers including: breast, leukemia, lymphoma, lung, osteosarcoma, bladder and in trophoblastic neoplasms (Herfarth et al., 2012).

Methotrexate is thought to be a chemotherapeutic and anti-inflammatory agent by two different pathways. Its anticancer effect occurs, by competitive inhibition of dihydrofolatereductase (DHFR), an enzyme that participates in the tetrahydrofolate synthesis. The lack of folate affects several biochemical pathways including purine metabolism and so, inhibits the synthesis of DNA, RNA and proteins (Abraham et al., 2010). 
Methotrexate is used in the treatment of rheumatoid arthritis due to inhibition of T-cell activation, selective down-regulation of $\mathrm{B}$ cells and inhibition of the binding of Interleukin-1 beta to its cell surface receptor (Alam et al., 2012).

Methotrexate is primarily cleared by the kidney. It concentrates in the kidney, gall bladder, spleen and in the liver. The most common adverse effects of MTX are hepatotoxicity, nephrotoxicity, ulcerative stomatitis, low white blood cell count and thus predisposition to infection, acute pneumonitis, and rarely pulmonary fibrosis (Asvadi et al., 2011).

Administration of high doses of MTX has been reported to cause severe renal toxicity \& acute renal failure due to accumulation of MTX crystals in the renal tubules leading to renal tubular obstruction and renal dysfunction. Furthermore, MTX has been reported to reduce the methionine synthesis \& antioxidant enzymes such as catalase, glutathione peroxidase and finally, increased reactive oxygen species in renal tissues. Therefore, nephrotoxicity is the most important side effect of MTX (UZ et al., 2005).

Zafirlukast is a synthetic ,selective cystinyl leukotriene receptor antagonist with a chemical name 4(5-Cyclopentoxy-Carbonylamino-1-Methyl-Indol-3-

Ylmethyl)-3-Methoxy-N- Otolylsulfonylbenzamide. Cysteinyl leukotrienes are lipid mediators derived from arachiodonic acid via the 5-lipoxygenase pathway (ElSwefy and Hassanen, 2009). Zafirlukast is a fine white to pale yellow powder that is particularly insoluble in water. It is soluble in ethanol and in tetrahydrofuran (Silverman et al., 2004; Bharathi et al., 2008).

Zafirlukast blocks the action of cystenyl leukotrienes, thus decrease the activation of neutrophils and decrease the release of mediators, enzymes, superoxides involved in the pathogenesis of bronchial asthma and other inflammatory conditions (Cuciureanu et al., 2008).

Zafirlukast has a renoprotective effect through many mechanisms such as suppression the release of inflammatory cytokines and inhibition of the infiltration of neutrophils into the renal tissues. It makes a balancing oxidant- antioxidant status and enhances the enzymatic activities (Barnes, 2011).

Owed to the few number of researches evaluating the renoprotective effects of zafirlukast, a cysteinyl leukotriene receptor antagonist, the objective of this study was to analyze the nephrotoxicity induced by
MTX and to evaluate the possible ameliorative effect of zafirlukast.

\section{Materials and Methods \\ Animals}

This work was carried out on 50 adult Wistar male albino rats (weighing approximately 200- $250 \mathrm{gm}$ ) of twelve weeks of age. The animals were obtained from Minia University Laboratory Animals Growing Center. The rats were housed in plastic cages, fed a standard laboratory diet and water and maintained at a laboratory temperature of $22 \pm 3^{\circ} \mathrm{C}$ and exposed to a 12 light, dark cycle. All aspects of animal care and treatment were carried out according to the local guide lines of the Ethical Committee of Faculty of Medicine- Minia University.

\section{Chemicals}

Methotrexatewas obtained from MinapharmPharmaceutical Company (CairoEgypt).Zafirlukast was obtained from Sigma Pharmaceutical Company (Cairo-Egypt). Ethanol (99\%) is acting as a solvent for Zafirlukast and it was obtained from El- Nasr Pharmaceutical Company.

\section{Animal treatment schedule:}

The animals were divided into 5 groups each composed of 10 rats as follow:

Group (1) ( -ve control group): fed a standard laboratory diet and water to show the normal parameters.

Group (2) (Ethanol- treated group (+ve control): the rats were given $1 \mathrm{ml} / \mathrm{kg}$ bw of ethanol $99 \%$ (a solvent for Zafirlukast) daily orally for 10 days. Ethanol must be diluted with saline just before intake with final concentration of ethanol was $2 \%$ according to Crespi et al., 1994 .

Group (3) (Methotrexate treated- group): the rats were injected I.P with MTX $(20 \mathrm{mg} / \mathrm{kg}$ bw), single injection according to Asvadi et al., 2011). MTX is used in different doses in human according to the type of neoplasm. Dose vary 10-40mg / Kg/ day (Abraham et al., 2010).

Group (4) (Zafirlukast-treated group): the rats were given zafirlukast $(40 \mathrm{mg} / \mathrm{kg}$ bw) once daily orally for 10 days according to Afaf et al., 2003.

Group (5) (Zafirlukast+ MTX treated group): the rats were given zafirlukast by the same previous dose 5 days before and 5 days after MTX administration. MTX was given by the same previous dose according to (Ihab and Naglaa, 2014). Rats will be sacrificed after the $10^{\text {th }}$ day from methotrexate intake.

Rats were sacrificed by decapitation after light ether anesthesia and dissected at the end of the experiment. All approved conditions used for animal housing and handling were considered. The experimental protocol used followed the regulations for administration 
and painless sacrifice of the experimental animals. The animals were acclimatized prior to starting dosing for a period of one week. The kidney was dissected and subjected to light and electronic microscopic investigation. The remaining kidney tissue was subjected to biochemical studies (malondialdehyde (MDA), reduced glutathione (GSH) catalase and superoxide dismutase levels). Blood samples were collected for assaying the level of blood urea nitrogen and serum creatinine.

\section{Biochemical studies}

After sacrification, blood samples were withdrawn from the recto-orbital plexus of veins using a capillary pipette and collected in heparinised tubes and centrifuged at $3000 \mathrm{rPm}$ for $15 \mathrm{~min}$. and stored at $-20^{\circ} \mathrm{C}$ until required. The samples were subjected for the estimation of:

1-Blood urea nitrogen (BUN): It is an enzymatic colorimetric test. The kits were obtained from Biomed Diagnostics, Egypt (Patton and Crouch, 1977).

2-Serum creatinine: photometric colorimetric test for kinetic measurements method without deprotinisation. The kits were obtained from Spectrum Diagnostics (Bowers and Wong, 1980).

Malondialdehyde(MDA), reduced glutathione (GSH), catalase and superoxide dismutase assays:kidneys were dissected and separated and homogenized in 1:10 (wt: vol) $0.1 \mathrm{M}$ phosphate buffer (pH 7.4) by the use of a Teflon headed homogenizer. Triton x100 and protease inhibitor cocktail were added. The homogenates were centrifuged at $6.000 \mathrm{~g}$ for $10 \mathrm{~min}$ at $4^{\circ} \mathrm{C}$ and the supernatant was used to measure MDA, GSH, catalase and superoxide dismutase levels. All of the above parameters were obtained from Bio-diagnostic Company, colorimetric method. MDAwas measured as described by Ohkawa et al., 1979.While GSH was measured according to Beutler et al., 1963.Catalase level was measured according to Aebi, 1984. Superoxide dismutase was measured as described by Paoletti and Mocali, 1990.

\section{Histopathological studies:}

Kidneys were removed and cut into Small pieces about 1 $\mathrm{mm}$ thick. Some pieces were fixed in $10 \%$ buffered formalin and processed for paraffin embedding by standard methods and sections of $6 \mu \mathrm{m}$ thicknesses were deparaffinized with xylene and stained with hematoxylineosin to be viewed by Olympus light microscope (Olympus BX51, Tokyo, Japan) with an attached camera (Cannon 620) (Bancroft et al., 2002). Brightness, contrast were adjusted using Adobe Photoshop software.

For ultrastructural study, tissues were removed and placed in $2.7 \%$ glutaraldehyde- $0.1 \mathrm{M}$ phosphate buffer solution for $2 \mathrm{hr}$, and then flooded in 4 consecutive baths of the same fixative $0.15 \mathrm{M}$ phospate buffer $\left(4{ }^{\circ} \mathrm{C}\right)$ for $1 \mathrm{hr}$ each .The samples were postfixed in a $2 \%$ osmic acid$0.15 \mathrm{M}$ phosphate buffer solution $\left(4{ }^{\circ} \mathrm{C}\right)$ for $1 \mathrm{hr}$, and again 4 times flooded in $0.15 \mathrm{Mphosphate}$ buffer solution for $15 \mathrm{~min}$ each .Samples were acetone dehydrated, and embedded in polyesteric resin, polymerized at $60^{\circ} \mathrm{C}$ for 72 hrs(Semithin sections $(1 \mu \mathrm{m})$ stained with toluidine blue. Ultrathin sections were made using ultramicrotome, and double contrasted with uranyl acetate and lead citrate solutions (Aguas, 1982), and examined by JEOL electron microscope (JEM-100CXII) equipped with a camera.

\section{Statistical analysis}

Values were expressed as mean \pm standard deviation (SD). The data were analyzed by using SPSS for windows (version 16.0). The significance of differences was calculated by using ANOVA test with Post Hoc LSD analysis for comparison between groups.. $\mathrm{P}<0.05$ was considered significant.

\section{Results}

\section{Results of biochemical studies}

The ethanol and zafirlukast-treated groups show non significant difference from the -ve control one regarding of BUN and serum creatinine levels, butMTX and zafirlukast plus MTX- treated groups had significantly higher BUN and serum creatinine levels than the control groups. However, the zafirlukast plus MTX-treated rats had significantly lowerBUN and serum creatinine level than the MTX-treated group (table 1).

The control, ethanol and zafirlukast- treated rats had equivalent MDA level, but the MTX and zafirlukast plus MTX- treated rats had significantly higher MDA level than the control group. The MTX and the zafirlukast plus MTX- treated rats had significantly higher MDA level than the ethanol- treated rats. However, the zafirlukast plus MTX- treated rats had significantly lower MDA level than the MTX- treated rats (table 2).

The ethanol and zafirlukast- treated groups did not differ significantly from the control rats in terms of GSH level, but the MTX and zafirlukast plus MTX treated rats had significantly lower reduced glutathione level when compared with the control rats. However, zafirlukast plus MTX- treated rats had significantly higher reduced glutathione level when compared with the MTXtreated group (table 3).

The control, , ethanol and zafirlukast- treated groups had equivalent catalase level, but the MTX and zafirlukast plus MTX treated groups had significantly lower catalase level when compared with the control group. However, zafirlukast plus MTX treated group had significantly higher catalase level when compared with the MTX treated- group (table 4). 
The ethanol and zafirlukast- treated groups did not differ significantly from the control rats in terms of superoxide dismutase level, but the MTX and zafirlukast plus MTX - treated rats had significantly lower superoxide dismutase level when compared with the control rats. However, zafirlukast plus MTX- treated rats had significantly higher superoxide dismutase level when compared with the MTX- treated group (table 5).

\section{Histopathological findings in the kidney}

The light microscopic examination of the kidney of the control, ethanol and zafirlukast treated groups revealed the normal structure of the kidney which composed of renal glomeruli \& tubules. The glomeruli consist of fenestrated capillaries with mesengial cells in between the capillary loops. The renal tubules are spherical in shape \& lined by small columnar epithelial cells (fig 1a).

The kidney tissue of MTX-treated group showed cloudy swelling with inflammatory cellular changes in which the cells of the convoluted tubules are swollen \& conical in shape with swollen nuclei(fig 1b). There is severe congestion of the renal tissue with marked inflammation (fig 1c).MTX-treated group showed interstialoedema\&glomerulosclerosis in which there is diffuse thickening of the capillary wall \& basement membrane (fig 1d \&1e). Necrosis of kidney tissue appeared as loss of normal architecture of kidney \& the cells lost their nuclei and marked necrotic cells appeared (fig 1f).Administration of zafirlukast in group (5) restored the normal architecture of kidney, only dilated renal tubules appeared (fig 1g).

Ultra structural analysis of kidney tissues of the control, ethanol and zafirlukast-treated groups revealed normal architecture of renal tissue in which there is normal structure of basement membrane, normal shape of nucleus and mitochondria with normal podocytes (fig 2a\&b).

Ultrastructural examination of kidney tissues of MTX-treated group revealed irregular pyknotic nucleus with degenerated podocytes(fig 2c). Also, there is degenerated mitochondria (faint matrix \& no crestae) and degenerated cytoplasm (fig 2d). Fine structural features of the kidney tissues of zafirlukast + MTX treated group revealed that the most renal tissue retained its normal architecture (fig 2e).

Table (1): Comparison of BUN \& serum creatinine levels between different experimental groups using ANOVA test with Post Hoc LSD analysis $(n=10)$.

\begin{tabular}{|c|c|c|c|c|c|c|}
\hline \multicolumn{6}{|c|}{ BUN level(mg/dl) } & \multirow[t]{2}{*}{$P$ value } \\
\hline & Group I & Group II & Group III & Group IV & Group V & \\
\hline Mean \pm SD & $23.51 \pm 0.8$ & $24.09 \pm 1.2$ & $58.74 \pm 3.2$ & $23.82 \pm 0.7$ & $32.52 \pm 2.4$ & $<0.001^{*}$ \\
\hline \multicolumn{6}{|c|}{ Post Hoc LSD analysis } & \\
\hline Group I & & 0.504 & $<0.001^{*}$ & 0.721 & $<0.001^{*}$ & \\
\hline Group II & & & $<0.001^{*}$ & 0.756 & $<0.001^{*}$ & \\
\hline Group III & & & & $<0.001^{*}$ & $<0.001^{*}$ & \\
\hline Group IV & & & & & $<0.001^{*}$ & \\
\hline \multicolumn{6}{|c|}{ Creatinine level (mg/dl) } & \\
\hline & Group I & Group II & Group III & Group IV & Group V & \\
\hline Mean \pm SD & $0.57 \pm 0.06$ & $0.58 \pm 0.07$ & $0.89 \pm 0.07$ & $0.56 \pm 0.08$ & $0.65 \pm 0.04$ & $<0.001^{*}$ \\
\hline \multicolumn{6}{|c|}{ Post Hoc LSD analysis } & \\
\hline Group I & & 0.734 & $<0.001 *$ & 0.734 & 0.009* & \\
\hline Group II & & & $<0.001^{*}$ & 0.478 & $0.021 *$ & \\
\hline Group III & & & & $<0.001^{*}$ & $0.004^{*}$ & \\
\hline Group IV & & & & & $<0.001^{*}$ & \\
\hline
\end{tabular}

$* P<0.05$ was considered significant. 
Table (2): Comparison of MDA level between different experimental groups using ANOVA test with Post Hoc LSD analysis $(n=10)$.

\begin{tabular}{|c|c|c|c|c|c|c|}
\hline \multicolumn{6}{|c|}{ MDA level( nmol/gm tissue) } & \multirow[t]{2}{*}{ P value } \\
\hline Group & Group I & Group II & Group III & Group IV & Group V & \\
\hline Mean \pm SD & $28.16 \pm 1.5$ & $29 \pm 1.2$ & $48.22 \pm 3.1$ & $28.55 \pm 0.98$ & $32.38 \pm 0.57$ & $<0.001^{*}$ \\
\hline \multicolumn{6}{|c|}{ Post Hoc LSD analysis } & \\
\hline Group I & & 0.277 & $<0.001^{*}$ & 0.612 & $<0.001^{*}$ & \\
\hline Group II & & & $<0.001^{*}$ & 0.559 & $<0.001^{*}$ & \\
\hline Group III & & & & $<0.001^{*}$ & $<0.001^{*}$ & \\
\hline Group IV & & & & & $<0.001^{*}$ & \\
\hline
\end{tabular}

${ }^{*} P<0.05$ was considered significant.

Table (3): Comparison of GSH level between different experimental groups using ANOVA test with Post Hoc LSD analysis $(\mathbf{n}=10)$.

\begin{tabular}{|c|c|c|c|c|c|c|}
\hline \multicolumn{6}{|c|}{ GSH level( mg/gm tissue) } & \multirow[t]{2}{*}{ P value } \\
\hline Group & Group I & Group II & Group III & Group IV & Group V & \\
\hline Mean \pm SD & $212.03 \pm 15.3$ & $213 \pm 10.11$ & $120.2 \pm 19.22$ & $212.44 \pm 11.08$ & $180.97 \pm 14.20$ & $<0.001^{*}$ \\
\hline \multicolumn{6}{|c|}{ Post Hoc LSD analysis } & \\
\hline Group I & & 0.881 & $<0.001 *$ & 0.949 & $<0.001^{*}$ & \\
\hline Group II & & & $<0.001^{*}$ & 0.931 & $<0.001^{*}$ & \\
\hline Group III & & & & $<0.001 *$ & $<0.001 *$ & \\
\hline Group IV & & & & & $<0.001^{*}$ & \\
\hline
\end{tabular}

${ }^{*} P<0.05$ was considered significant.

Table (4): Comparison of catalase level between different experimental groups using ANOVA test with Post Hoc LSD analysis $(\mathbf{n}=10)$.

\begin{tabular}{|c|c|c|c|c|c|c|}
\hline \multicolumn{6}{|c|}{ Catalase level( U/gm tissue) } & \multirow[t]{2}{*}{$P$ value } \\
\hline Group & Group I & Group II & Group III & Group IV & Group V & \\
\hline Mean \pm SD & $50.08 \pm 10.5$ & $51.01 \pm 9.2$ & $36.22 \pm 6.8$ & $50.72 \pm 8.7$ & $46.31 \pm 3.6$ & $<0.001^{*}$ \\
\hline \multicolumn{6}{|c|}{ Post Hoc LSD analysis } & \\
\hline Group I & & 0.799 & $<0.001^{*}$ & 0.861 & $<0.001^{*}$ & \\
\hline Group II & & & $<0.001^{*}$ & 0.937 & $<0.001^{*}$ & \\
\hline Group III & & & & $<0.001^{*}$ & $<0.001^{*}$ & \\
\hline Group IV & & & & & $<0.001 *$ & \\
\hline
\end{tabular}

${ }^{*} P<0.05$ was considered significant.

Table (5): Comparison of superoxide dismutase level between different experimental groups using ANOVA test with Post Hoc LSD analysis $(n=10)$.

\begin{tabular}{|c|c|c|c|c|c|c|}
\hline \multicolumn{6}{|c|}{ Superoxide dismutase level( U/gm tissue) } & \multirow[t]{2}{*}{ P value } \\
\hline Group & Group I & Group II & Group III & Group IV & Group V & \\
\hline Mean \pm SD & $152.5 \pm 5.6$ & $153.02 \pm 8.5$ & $128.8 \pm 9.7$ & $152.08 \pm 20.7$ & $148.07 \pm 8.1$ & $<0.001^{*}$ \\
\hline \multicolumn{6}{|c|}{ Post Hoc LSD analysis } & \\
\hline Group I & & 0.884 & $<0.001^{*}$ & 0.906 & $<0.001^{*}$ & \\
\hline Group II & & & $<0.001^{*}$ & 0.792 & $<0.001^{*}$ & \\
\hline Group III & & & & $<0.001^{*}$ & $<0.001^{*}$ & \\
\hline Group IV & & & & & $<0.001^{*}$ & \\
\hline
\end{tabular}

${ }^{*} P<0.05$ was considered significant. 


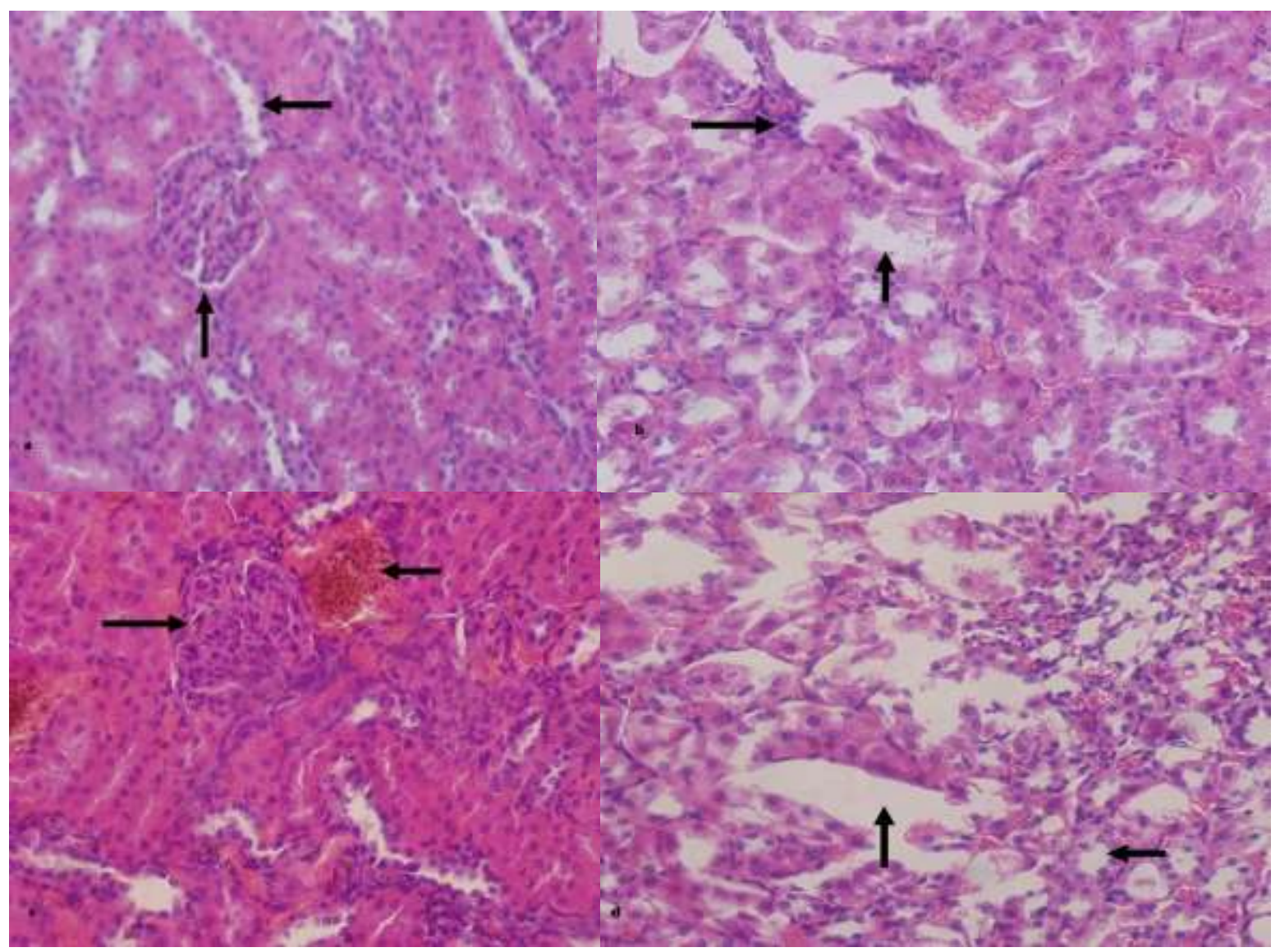

Figure (1): photomicrograph of a section of kidney a) control,ethanol and zafirlukastgroups showing the normal structure of renal glomeruli $(\uparrow)$ and renal tubule $(\leftarrow)$. b) MTX group showing cloudy swelling $(\uparrow)$ in which the cells of the convoluted tubules are swollen and conical in shape with marked inflammatory cellular changes $(\rightarrow)$. C) MTX group showing severe congestion of the renal tissue $(\leftarrow)$ with multiple inflammatory cells $(\rightarrow)$. MTX group showing interstialoedema $(\uparrow)$ with cloudy swelling $(\leftarrow) . H \& E X 400$. 

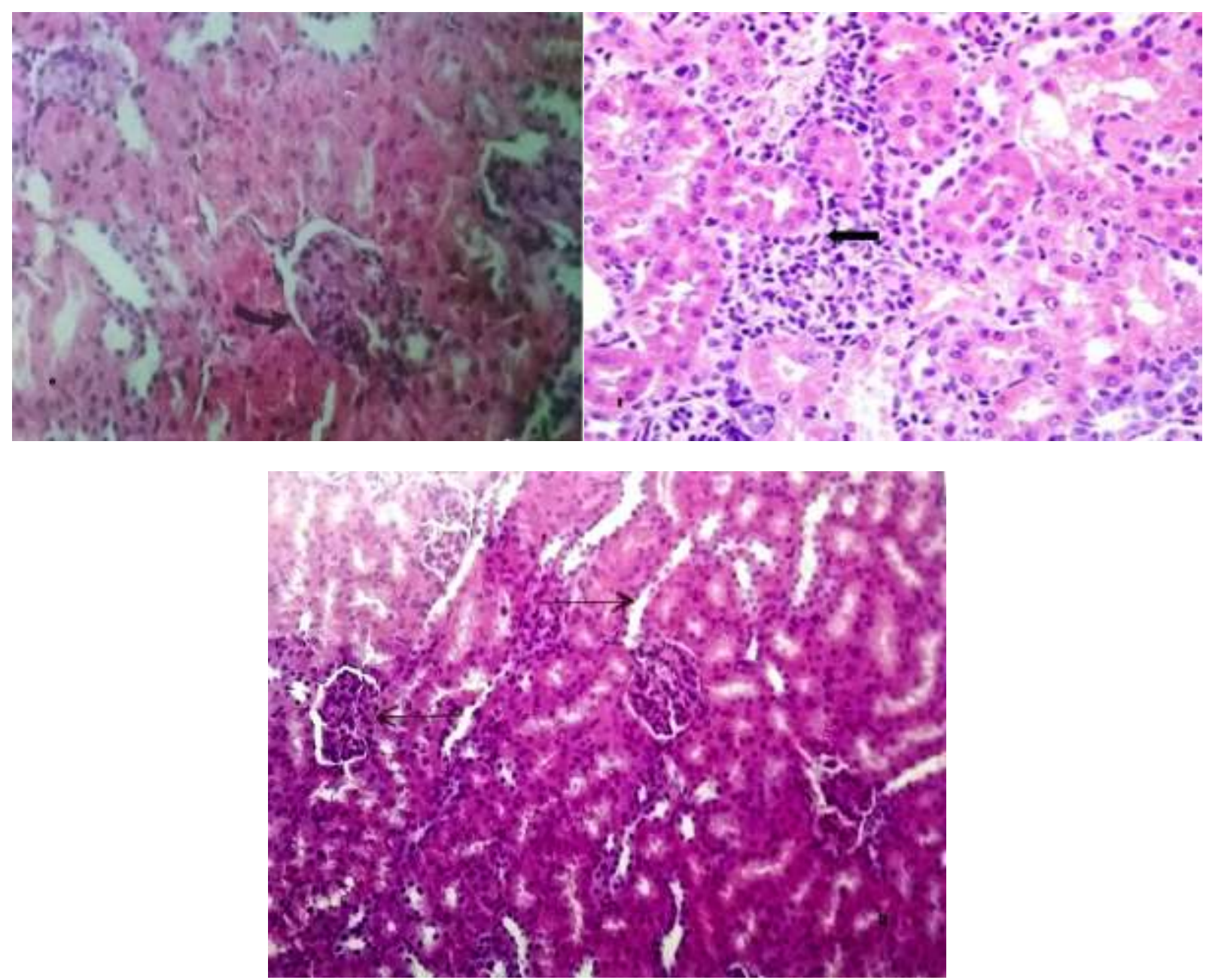

Figure (1): photomicrograph of a section of kidney e) MTX group showing glomerulosclerosis in which there is diffuse thickening of the capillary wall and thickening of basement membrane $f$ ) MTX group showing necrosis of the renal tissue $(\leftarrow)$ wichappeared as loss of normal architecture of the tissue and the cells lost their nuclei and marked necrotic cells appeared. g) Adminstration of zafirlukast with MTX restored the normal architecture of the kidney and only dilated renal tubules appeared $(\rightarrow)$ H\&EX400. 

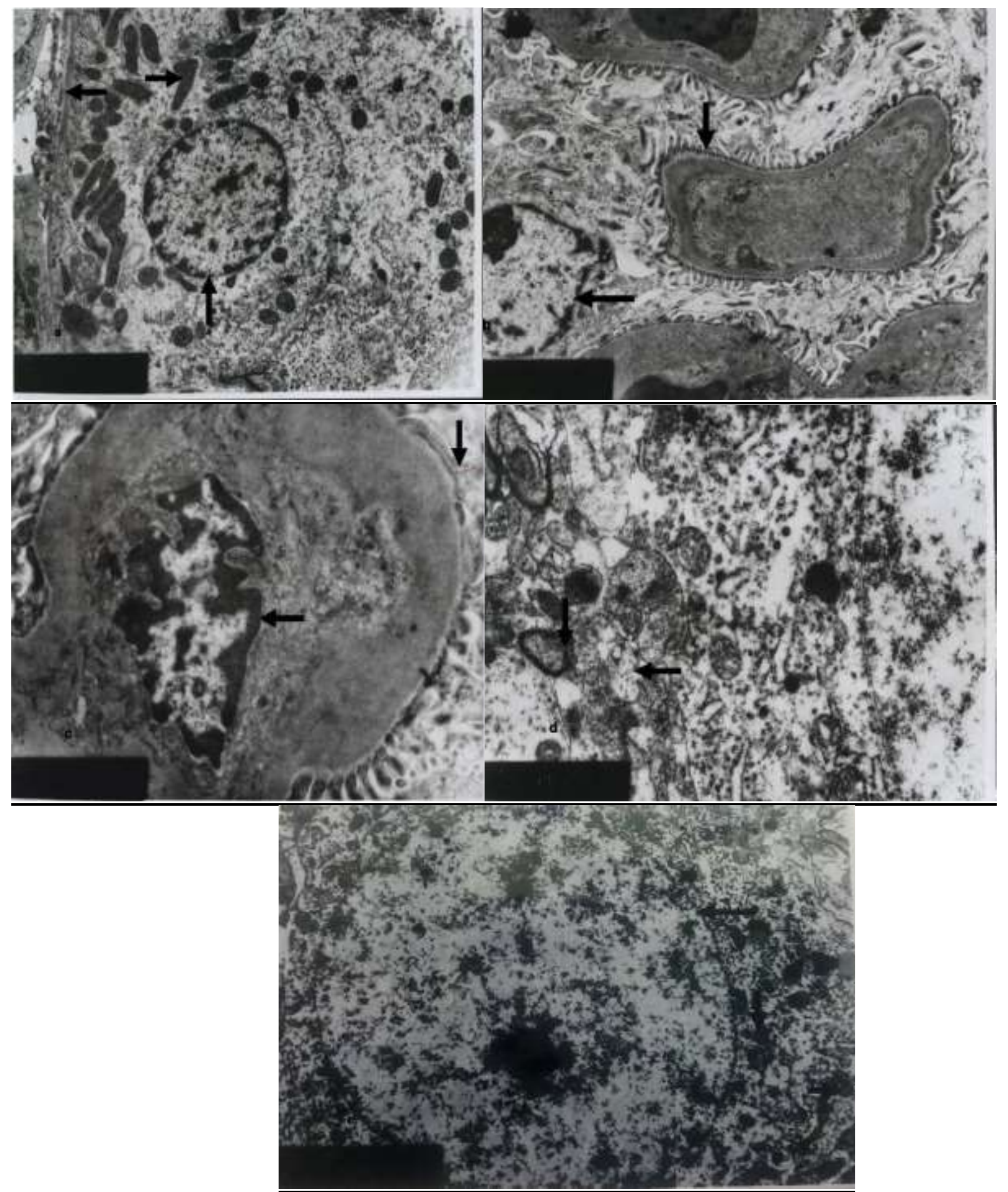

Figure (2): electron micrograph a,b of control, ethanol and zafirlukast treated rat kidney showing normal structure of basement membrane $(\leftarrow)$, normal shape and structure of mitochondria $(\rightarrow)$, nucleus $(\uparrow)$ and podocytes $(\downarrow)$ ). In MTX group (fig 2c, 2d), there is irregular pyknotic nucleus $(\leftarrow)$ ), degeneratedpodocytes $(\downarrow)$ and degenerated mitochondria (no creaste, and faint matrix). Fig $2 \mathrm{e}$ showing that the most renal tissue retained the normal structure of kidney (normal nuclear membrane $(\leftarrow)$ and mitochondria $(\downarrow)$. 


\section{Discussion}

MTX is classified as an antimetabolite drug, which means that it is capable of blocking the metabolism of cells. It is widely used to treat many disorders such as leukemia, osteosarcomas, and autoimmune disorders. Also, it is the most common anti-rheumatic drug that's used to treat rheumatoid arthritis and other rheumatic disorders e.g psoriasis \& systemic lupus erythermatosus (Oktem et al., 2006).

Cancer occurs when the cells grow very rapidly in an uncontrolled way. The cancer cells need new DNA that helps it to grow. When MTX was administered, cancer cells can't make DNA and this kills cancer cells. The risk of toxicity of MTX increased when it was used at a high dose \& for a long period (Vardi et al., 2008).

MTX is a chemotherapeutic agent that is structurally similar to folic acid. It inhibits dihydrofolatereductase, an enzyme that reduces folic acid to tetrahydrofolic acid. MTX enters the cell via active transport across the reduced folate carrier, where it is effluxed from the cell by several of the ATPbinding Cassette (ABC) transporters, especially ABCC1-S, ABCG-2 (Radtke et al., 2013).

Methotrexate toxicity develops due to increased patient susceptibility during treatment, excessive parenteral or intrathecal administration, therapeutic errors by patients (e.g taking orally daily instead of weekly, self administration to induce abortion or intentional oral overdoses (Christensen et al., 2012). Toxicity of MTX depends on whether the patient is on low-dose MTX (e.g for rheumatoid arthritis) or on highdose (e.g chemotherapy) (Mol et al., 2008).

Clinical manifestations of toxicity include nausea, vomiting, diarrhea, mucositis, stomatitis, rash, acute lung injury manifestations (dyspnea, cyanosis, tachypnea, chest pain), tachycardia, hypotension, myelosuppersion (leucopenia, pancytopenia, thrombocytopenia) and neurological disfunction (e.g depression, headache, seizures, encephalopathy and coma) (Suzuki et al., 2009).High doses of MTX have been associated with gastrointestinal, hepatic, nervous, renal and bone marrow toxicity. $90 \%$ of MTX is excreted through the kidney \& so nephrotoxicity is the most common toxic effect of MTX treatment. Renal function disturbances induced by MTX delays its excretion, so resulting in enhancement of other toxicities of MTX (Vardi et al., 2013).

Cysteinylleukotrienes (LTC4, LTD4 and LTE4) are lipid mediators derived from arachiodonic acid through the 5- lipooxygenase pathway. Whereas LTB4 is identified as apotent chemotactic for neutrophils leading to degranulation and release of mediators, enzymes and superoxides (Jain et al., 2001; El-Swefy andHassanen, 2009).
Zafirlukast is an orally synthetic leukotriene receptor antagonist which is widely used for the prophylaxis and chronic treatment of athma. It's rapidly absorbed following oral administration. Its peak plasma concentration was generally occurred 3 hours after oral administration. Zafirlukast is extensively metabolized in liver. It is excreted mainly in feces. Urinary excretion accounts for approximately $10 \%$ of the dose (Aagaard and Hansen, 2014).

The objective of this study was to assess the toxicity of MTX on kidney through measuring serum creatinine \& BUN levels, oxidative stress markers (MDA, GSH, catalase and superoxide dismutase) and the pathological changes in kidney and to investigate the role of zafirlukast as a protective agent.

In the present study, MTX was given at a dose of $20 \mathrm{mg} / \mathrm{kg}$ bw I.P, single injection. Severe pathological changes were observed in the kidney of rats, although none of the rats died during the experimental period. The dose \& route of administration of MTX in this study were in accordance with the study of Asci et al., (2011); Asvadi et al., (2011); Ihab and Naglaa, (2014). While in the study of Ehab et al., (2014), MTX was injected intraperitoneally by a dose of $0.5 \mathrm{mg} / \mathrm{kg}$ twice a week for four weeks. In the study of Chelab and Majeed, (2009) MTX was given intramuscularly at different doses for six months.

Single injection of toxic dose of MTX in this study led to significant renal toxicity which represented by increased levels of BUN, serum creatinine \& increase the level of lipid peroxides (MDA), in addition there was a significant decrease in antioxidant enzymes as GSH, catalase and superoxide dismutase contents of kidney homogenate. These results agree with the results of Asci et al., (2011); Ehab et al., (2014). Their study revealed that MDA level was significantly increased and the activities of superoxide dismutase (SOD) and catalase (CAT) were significantly decreased in MTX administred rats than the control rats in both liver and kidney tissues.

Also Asvadi et al., (2011); Ihab and Naglaa, (2014) conducteda study to assess the renal toxicity of MTX. Their study revealed significant increase in the level of BUN, Serum creatinine, MDA level, tumor necrosis factor alpha and nuclear factor kappa beta protein expression in MTX treated animals. Their results were also in agreement with the results of the present study.

Oxidative stress is an indicator to the damage that occurred as a result of the change in the balance between oxidants and antioxidants. If the balance between oxidants and antioxidants can't be occurred in tissues, severe pathological changes and cellular damage occur. Oxidative stress \& oxidative cellular damage due to the profound lipid peroxidation and the 
release of free oxygen radicals explain the toxic renal effects of MTX (Ciralik et al., 2006; Jahovic et al., 2004).

Creatinine concentration is more significant than BUN level in the earlier phases of kidney disease. BUN starts to rise only after marked renal parenchymal injury \& glomerular filteration rate has diminished to less than (50\%) of normal (Vardi et al., 2013; Dabak and Kocaman, 2013).

Aly (2012) conducted a study to explain the changes that occurred in BUN \& serum creatinine by chemotherapeutic agents toxicity. Adriamycin and MTX may act directly on the tubular epithelium or participate within the tubular lumen leading to intratubular obstruction and damage of renal tubular cells. This damage interfered with the tubular cell renewal and impairment of renal cell function causing a decline in GFR. Also, the cells started to slough into the lumen of the tubules resulting in slowing of the flow of tubular fluid and rise of BUN and serum creatinine levels.

The present study proved that MTX toxicity induced pathological changes in the kidney in the form of severe inflammation, congestion, interstialoedema, necrosis and glomerulosclerosis by light microscopic examination. Ultrastructural changes induced by MTX were irregular pyknoticnucleui, degenerated podocytes, mitochondria and cytoplasm. These results are in agreement with the results of the study of Mohamed et al., (2013); Chelab and Majeed (2009).

The pathological changes induced by MTX can be explained by the ability of MTX to penetrate the cell membrane easily and generate various radicals as superoxide radical, nitrogen species such nitric oxide and hydroxyl radical. All these radicals attack the cell membrane and led to destabilization and disintegration of cell membrane as a result of lipid peroxidation (Prahalathan et al., 2005; Atiaf, 2010).

Pre \& post-treatment of zafirlukast with MTX in this present study induced a significant decrease in BUN, serum creatinine levels and MDA. Also, it induced a significant increase in GSH, catalase, and superoxide dismutase levels when compared with MTXtreated rats.Administration of zafirlukast with MTX restored the normal architecture of the kidney and only slight renal tubular dilatation was seen in the kidney.

Few literatures and researches evaluated the protective effect of zafirlukast on renal toxicity induced by MTX. Jain et al., (2001) observed that zafirlukast had a significant effect on exudate formation and migration of polymorphonuclear leukocytes in the carageenan-induced pleurisy model. They suggested that cystenylleukotrienes involved in inflammatory conditions.

The ameliorative effect of zafirlukast that has been observed in this study can be explained by the fact that zafirlukast is a cystenyllekotriene antagonist especially against LTB4. LTB4 is a potent chemotactic agent for neutrophils, eosinophils and monocytes. It promotes their adhesion to the vascular epithelium and enhances their migration across the endothelial cells into the surrounding tissues. LTB4 also increases the release of toxic oxygen products, lysosomal enzymes and cytokines from the pro-inflammatory cells (Chohnabayashi et al., 2007).

Zafirlukastcan suppress the release of inflammatory cytokines and enhance the enzymatic antioxidant activities. It reversed ischemic/reperfusion induced oxidant responses, improved microscopic damage of renal tissue by inhibiting neutrophil infilteration, balancing oxidant-antioxidant status and regulating the generation of inflammatory mediators (Davern and Bass , 2003; Barnes, 2011).

In conclusion, the present study showed that nephrotoxicity is considered as an important complication of MTX and zafirlukast has an ameliorating role in this toxicity concerning histopathological changes, oxidative stress \& biochemical investigations. Thus, it's advised the Ministry of Health to recommend the use of zafirlukast before and after treatment with MTX to protect the patients from the toxic renal hazards of MTX.

\section{Acknowledgement}

All thanks and appreciations to Dr/ Hebatawfik for her assistance in doing the histopathological studies in this research.

\section{References}

Aagaard L and Hansen EH ( 2014): Adverse drug reactions associated with asthma medications in children: systematic review of clinical trials. Int $\mathrm{J}$ Clin Pharm. 36:pp.243-52.

Abraham P, Kolli VK, Rabi S (2010):Melatonin attenuates methotrexate- induced oxidative stress and renal damage in rats. Cell BiochemFunct. 28: pp.426-433.

Aebi H (1984):Methods Enzymol . 105: pp. 121-126.

Afaf A, Azza A, Hanan H et al., (2003): Evaluating the prophylactic potential of zafirlukast against the toxic effects of acetic acid on the rat colon. Toxicology Letters. 145:pp. 79-87.

Aguas P (1982): The use of osmium tetraoxide potassium ferrocyanide as an extracellular marker in electron microscopy. Stain technology. 57: pp. 69-73.

Alam MK, Sutradhar SR, Pandit $\mathrm{H}$ et al., ( 2012): Comparative study on methotrexate and hydroxychloroquine in the treatment of rheumatoid arthritis. Mymensingh Med J. 21:pp. 391-398. 
Aly NH (2012): Reno-protective efficiency of coenzymes Q10 on adriamycin-induced nephrotoxicity in rats. Journal of applied sciences Research. 8:pp. 589-97.

Asci H, Ozer MK, Calapoglu M et al.,( 2011): Effects of Misoprostol on methotrexate-induced hepatic and renal damages. Journal of Biology \& Life Sciences. 2:pp.32-37.

Asvadi I, Hajipour B, Asvadi A et al., ( 2011): Protective effect of pentoxyfilline in renal toxicity after methotrexate administration. Eur Rev Med Pharmacol Sci. 15: pp.1003-1009.

Atiaf GR (2010): Protective effect of captopril against methotrexate-induced nephrotoxicity in mice. Kufa Journal for Veterinary Medical Sciences. 2:pp.38-47.

Bancroft JD, Stevens A , Turner DR (2002):Theory and practice of histological techniques. $4^{\text {th }}$ ed., New York: Churchill Livingstone, Ch. 3. pp. 564-388.

Barnes PJ (2011): Pulmonary pharmacology. In Brunton LL, Chabner BA, Knollman BC (eds.). Goodman and Gillman's the pharmacological basis of therapeutics. $12^{\text {th }}$ ed., New York: MacGrawHill,pp.1031-65.

Beutler E, Duron O, Kelly MB (1963):.J. Lab. Clin. Med .61: pp. 882.

Bharathi DV, Naidu A, Jagadeesh B et al., (2008). Development and validation of a sensitive LCMS/MS method with electrospray ionization for quantitation of zafirlukast , a selective leukotriene antagonist in human plasma: application to a clinical pharmacokinetic study. Biomed. Chromatogr.22:pp. 645-653.

Bowers LD and Wong ET (1980): Kinetic serum creatinine assays. II. A critical evaluation and review. Clin Chem. 26: pp. 555-561.

Chelab KG and Majeed SKH (2009): Methotrexate inducehistopathological changes in kidneys of mice. Iraq J. of Vet. Sci. 23:pp.219-222.

Chohnabayashi N, Sugiura R, Nishimura N (2007): Adverse effects of leukotriene-antagonists. Nippon Rinsho. 65:pp. 272-6.

Christensen AM, Pauley JL, Molinelli AR, et al.,( 2012): Resumption of high-dose methotrexate after acute kidney injury and glucarpidase use in pediatric oncology patients. Cancer. 118: pp. 4321.

Ciralik H, Bulbuloglu E, Cetinkaya A, et al., ( 2006): Effects of $\mathrm{N}$-acetylcysteine on methotrexate induced small intestinal damage in rats. The Mount Sinai Journal of Medicine. 73:pp.10861092.

CrespiF, Ratti E ,Trist DG (1994):Melatonin, a hormone monitorable in vivo by voltammetry? Analyst D .119:pp. 2193- 2197.

Cuciureanu M, Caruntu ID, Kuchar M, et al., (2008): The influence of leukotriene receptors' antagonists on experimentally induced ulcer in rats. Rev Med ChirSoc Med Nat Iasi. 112:pp. 750-756.

Dabak DO and Kocaman N (2013): Effects of silymarin on methotrexate-induced nephrotoxicity in rats. Ren Fail. 37:pp.734-9.

Davern TJ and Bass NM (2003): Leukotriene antagonists. Clin Liver Dis. 7:pp.501-12.

Ehab T, Zaki T, Walid A, et al., ( 2014): Methotrexateinduced hepatic and renal toxicity: role of $\mathrm{L}$ carnitine in treatment. Biomedicine and Biotechnology. 2:pp.85-92.

El-swefy S and Hassanen SI (2009): Improvement of hepatic fibrosis by leukotriene inhibition in cholestatic rats. Ann Hepatol. 8:pp. 41-49.

Herfarth HH, Long MD, Isaacs KL (2012): Methotrexate: underused and ignored?.Digestive Diseases. 30:pp. 112-8.

Ihab T and Naglaa F (2014): Renoprotective effects of montelukast, a cysteinyl leukotriene receptor antagonist, against methotrexate-induced kidney damage in rats. NaunynSchmiedeberg's Archives of Pharmacology. 387: pp.341-353.

Jahovic N, Sener G, Cevic H, et al., (2004): Amelioration of methotrexate-induced enteritis by melatonin in rats. Cell BiochemFunct .223:pp.22-28.

Jain NK, Kulkarni SK, Singh A(2001): Role of cysteinylleukotrienes in nociceptive and inflammatory conditions in experimental animals. Eur. J. Pharmacol. 423:pp. 85-92.

Miller Dr (2008): A tribute to Sidney Farber- the father of modern chemotherapy. British Journal of Haematology.134: pp.20-26.

Mohamed A, Salwa A, Entesar F, et al., (2013): Curcumin ameliorates methotrexate-induced nephrotoxicity in rats. Advances in pharmacological sciences.2013.pp.7.

Mol F, Mol BW, Ankum WM, et al.,( 2008): Current evidence on surgery, systemic methotrexate and expectant management in the treatment of tubal ectopic pregnancy: a systemic review and 
metanalysis. Human Reproduction Update. 14: pp.309-19.

Ohkawa H, Ohishi W ,Yagi K (1979): Biochem . 95: pp. 351.

Oktem F, Yilmaz HR, Ozguner F, et al., ( 2006): Methotrexate- induced renal oxidative stress in rats: the role of a novel antioxidant caffeic acid phenethyl ester. ToxicolInd Health. 22:241-7.

Patton CJ and Crouch S (1977): Spectrophotometric and kinetics investigation of the Berthelot reaction for the determination of ammonia. Anal Chem. 49: 464-9.

Paoletti F and Mocali A (1990): Determination of superoxide dismutase activity by purely chemical system based on NADPH oxidation. Methods Enzymol. 186: 209-20.

Prahalathan C, Selvakumar E, VaralakshmiP( 2005): Protective effect of lipoic acid on adriamycininduced testicular toxicity. ClinicaChimicaActa. 360:pp.160-166.

Radtke S, Zolk O, Renner B, et al.,( 2013): Germline genetic variations in methotrexate candidate genes associated with pharmacokinetics, toxicity, outcome in childhood acute lymphoblastic leukemia. Blood. 121:pp. 5145.

Silverman RA, Nowak RM, Korenblat PE ( 2004): Zafirlukast treatment for acute asthma.
Evaluation in a randomized, double-blind, multricenter trail.Chest. 126:pp.1480-1489.

Suzuki K, Doki K, Homma M, et al. ( 2009): Coadministration of proton pump inhibitors delays elimination of plasma methotrexate in high-dose methotrexated therapy. Br J ClinPharmacol. 67: pp.44.

Uz E, Oktem F, Yilmaz HR, et al., (2005): The activities of purine-catabolizing enzymes and the level of nitric oxide in rat kidneys subjected to methotrexate. Protective effect of caffeic acid phenethyl ester.Mol cell Biochem . 277: pp.165170.

Vardi N, Parlakpinar H, Ozturk F, et al., (2008): Potent protective effect of apricot and $\beta$-carotene on methotrexate induced intestinal oxidative damage in rats. Food and chemical toxicology. 46:pp. 3015-3022.

Vardi N, Parlakpinar H, Ates B, et al., ( 2013): The protective effect of Prunusarmeniaca L (apricot) against methotrexate-induced oxidative damage and apoptosis in rat kidney. J PhysiolBiochem. 69:pp. 371-81.

Weinblatt ME (2013): Methotrexate in rheumatoid arthritis: a quarter century of development. Transactions of the American Clinical and Climatological Association. 124: pp. 16-25. 


\title{
الملخص العربي
}

\section{التأثيرالحسن الخحتمل للزافرلوكاست علي التسمم الكلوى المسبب بالميثوتريكسات في حيوانات التجارب}

\author{
محمد فتحي عباس وشيرين عبد الحكيم الشربينى 1و رشا فؤاد أحمد2
}

يعتبر الميثوتريكسات عنصر كيماوي علاجي ويعتبر التسمم الكلوى عرض جانبي مهم للعلاج بالميثوتريكسات.ويستخدم الزافرلوكاست المضاد للسستانيل ليكوترين كمضاد للالتهاب والاكسدة.لذلك كان الهدف من الدراسة هو تحليل التسمم الكلوى الناتج عن الميثوتريكسات في الفئران وتقييم التأثير المحسن المحتمل للزافرلوكاست. وقد تم اعطاء الفئران (الايثانول امل/كجم ,مرة يوميا) و (الزافرلوكاست · عجم كجم , مرة يوميا) لمدة · ا أيام, (الميثوتريكسات · بعجم/كجم, يكقن بريتونيا مرة واحدة فقط) , وأخيرا (الزافرلوكاست · عجم/كجم ) و يعطى ه أيام قبل الميثوتريكسات ثم يعطي بعد العنصرالكيماوي بخمسة أيام. ويتم ز بح الفئران بعد · ا أيام من اعطاء الميثوتريكسات. و قد أسفرت الدراسة عن وجود زيادة ذات دلالة احصائية في مئي معدل المالوندايالدهيد وزيادة في مستوى الكرياتينين واليوريا في الدم في الفئران التي أخذت الميثوتريكسات ووجود قلة ذات دلالة احصائية في معدل الجلوتاثيون والكتالاز و السوبر أوكسيد ديسميوتاز في النسيج الكلوي وذلك عند مقارنتها بالمجموعة الضابطة. وقد لوحظ تأثير محسن على النتائج السابقة عند اعطاء مزيج من الميثوتريكسات والزافرلوكاست. وقد أظهرت صور الميكروسكوب الضوئي والالكتروي عن وجود تحلل شديد في كلى الفئران عند اعطاء الفئران الميثوتريكسات وعند اضافة الزافرلوكاستتم استعادة الهيكل التكوينى للكلي في الفئران. ولذلك نستخلص من هذه الدراسة أن الميثوتريكسات له القدرة علي احداث تلف تأكسدي في كلي الفئران وأن الزافرلوكاست له تأثير محسن ضد هذا التلف. ا قسم الطب الثر عي و السموم الاكلينيكية ـ كلية الطب ـ جامعة المنيا ـ المنياـ مصر

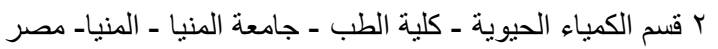

